\title{
Evaluation of the Relation between Evapotranspiration and Normalized Difference Vegetation Index for Downscaling the Simplified Surface Energy Balance Model
}

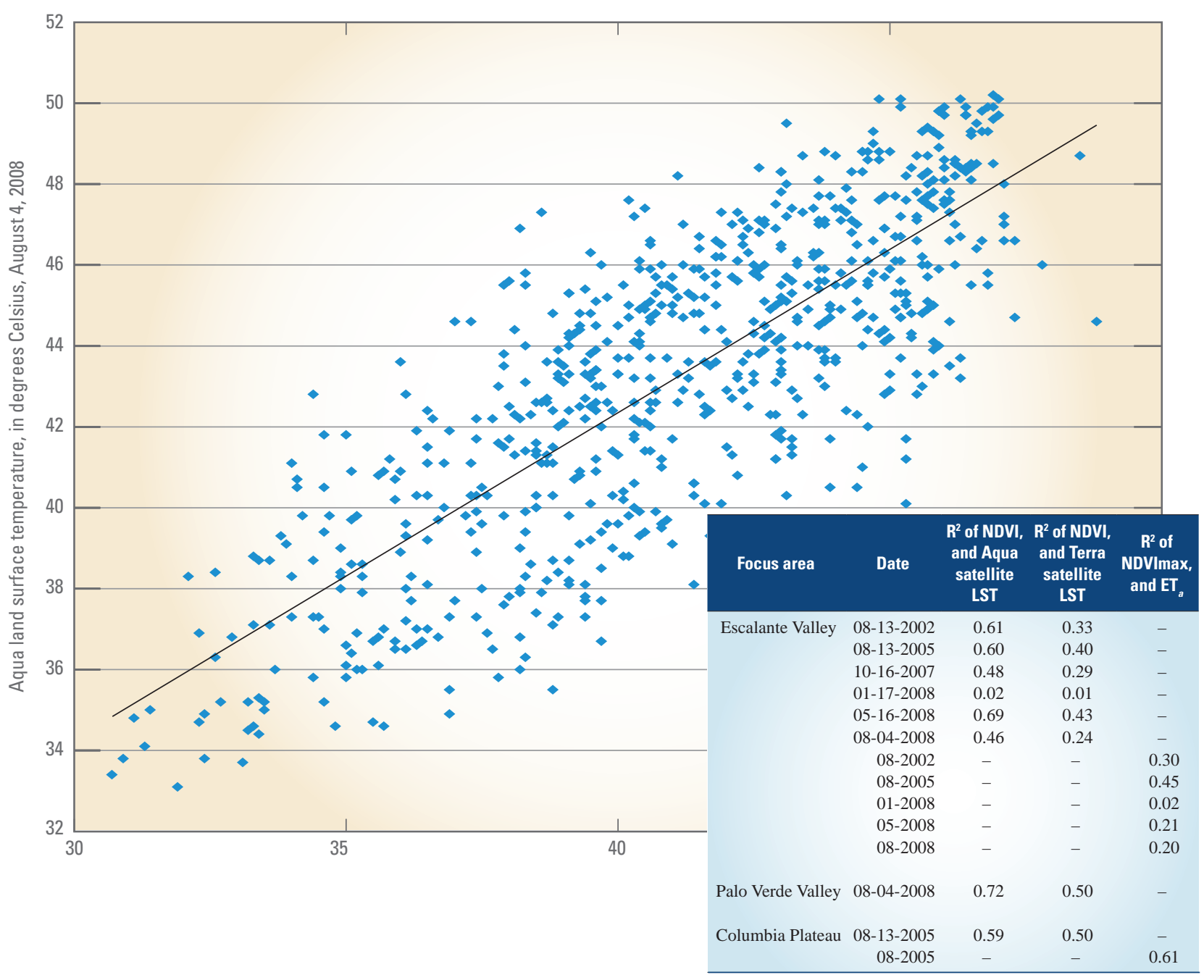

Scientific Investigations Report 2012-5197 



\section{Evaluation of the Relation between Evapotranspiration and Normalized Difference Vegetation Index for Downscaling the Simplified Surface Energy Balance Model}

By Jonathan V. Haynes and Gabriel B. Senay

Groundwater Resources Program

Scientific Investigations Report 2012-5197 


\title{
U.S. Department of the Interior \\ KEN SALAZAR, Secretary \\ U.S. Geological Survey \\ Marcia K. McNutt, Director
}

\author{
U.S. Geological Survey, Reston, Virginia: 2012
}

For more information on the USGS - the Federal source for science about the Earth, its natural and living resources, natural hazards, and the environment, visit http://www.usgs.gov or call 1-888-ASK-USGS.

For an overview of USGS information products, including maps, imagery, and publications, visit http://www.usgs.gov/ pubprod

To order this and other USGS information products, visit http://store.usgs.gov

Any use of trade, product, or firm names is for descriptive purposes only and does not imply endorsement by the U.S. Government.

Although this report is in the public domain, permission must be secured from the individual copyright owners to reproduce any copyrighted materials contained within this report.

Suggested citation: Haynes, J.V., and Senay, G.B., 2012, Evaluation of the relation between evapotranspiration and normalized difference vegetation index for downscaling the simplified surface energy balance model: U.S. Geological Survey Scientific Investigations Report 2012-5197, 8 p. 


\section{Contents}

Abstract
Introduction.
Purpose And Scope
Simplified Surface Energy Balance
Methods
Results
Summary
References Cited

\section{Figures}

Figure 1. Maps showing an eastward shift in actual evapotranspration $\left(\mathrm{ET}_{a}\right)$ compared to maximum monthly Normalized Difference Vegetation Index (NDVImax) and Landsat, Escalante Valley focus area near Enterprise, Utah ...

Figure 2. Maps showing an eastward shift in Mmoderate Resolution Imaging Spectroradiometer (MODIS) Terra land-surface temperature (LST) compared to MODIS Aqua LST and Normalized Difference Vegetation Index (NDVI), Escalante Valley focus area near Enterprise, Utah .5

Figure 3. Scatter plots of Aqua and Terra satellite correlations for land-surface temperature (LST) and Normalized Difference Vegetation Index (NDVI), Escalante Valley focus area near Enterprise, Utah . .6

\section{Tables}

Table 1. Correlations between Simplified Surface Energy Balance derived actual evapotranspiration, Moderate Resolution Imaging Spectroradiometer (MODIS)

Normalized Difference Vegetation Index, maximum monthly Normalized Difference Vegetation Index, and MODIS land-surface temperature for the Escalante Valley, Utah, Palo Verde Valley, California, and Columbia Plateau, Washington, focus areas. 


\section{Conversion Factors, Datum, and Abbreviations and Acronyms}

\section{Conversion Factors}

\begin{tabular}{lcl}
\hline \multicolumn{1}{c}{ Multiply } & By & To obtain \\
\hline meter $(\mathrm{m})$ & Length & \\
kilometer $(\mathrm{km})$ & 3.281 & foot $(\mathrm{ft})$ \\
\end{tabular}

Temperature in degrees Celsius $\left({ }^{\circ} \mathrm{C}\right)$ may be converted to degrees Fahrenheit $\left({ }^{\circ} \mathrm{F}\right)$ as follows:

$$
{ }^{\circ} \mathrm{F}=\left(1.8 \times{ }^{\circ} \mathrm{C}\right)+32
$$

\section{Datum}

Horizontal coordinate information is referenced to the World Geodetic Survey Datum of 1984 (WGS 84).

\section{Abbreviations and Acronyms}

$\begin{array}{ll}\mathrm{ET}_{a} & \text { actual evapotranspiration } \\ \mathrm{ET}_{f} & \text { evapotranspiration fraction } \\ \mathrm{ET}_{o} & \text { reference evapotranspiration } \\ \text { GDAS } & \text { Global Data Assimilation System } \\ \text { GIS } & \text { Geographic Information System } \\ \text { LST } & \text { land-surface temperature } \\ \text { METRIC } & \text { Mapping EvapoTranspiration at High Resolution and with Internalized Calibration } \\ \text { MODIS } & \text { Moderate Resolution Imaging Spectroradiometer } \\ \text { NASA } & \text { National Aeronautics and Space Administration } \\ \text { NDVI } & \text { Normalized Difference Vegetation Index } \\ \text { NDVImax } & \text { maximum monthly Normalized Difference Vegetation Index } \\ \text { PRISM } & \text { Parameter-elevation Regressions on Independent Slopes Model } \\ \text { SEBAL } & \text { Surface Energy Balance Algorithm for Land } \\ \text { SSEB } & \text { Simplified Surface Energy Balance } \\ \text { WGS84 } & \text { World Geodetic System 1984 }\end{array}$




\title{
Evaluation of the Relation between Evapotranspiration and Normalized Difference Vegetation Index for Downscaling the Simplified Surface Energy Balance Model
}

\author{
By Jonathan V. Haynes and Gabriel B. Senay
}

\begin{abstract}
The Simplified Surface Energy Balance (SSEB) model uses satellite imagery to estimate actual evapotranspiration $\left(\mathrm{ET}_{a}\right)$ at 1-kilometer resolution. $\mathrm{SSEB} \mathrm{ET} \mathrm{T}_{a}$ is useful for estimating irrigation water use; however, resolution limitations restrict its use to regional scale applications. The U.S. Geological Survey investigated the downscaling potential of $\mathrm{SSEB} \mathrm{ET}_{a}$ from 1 kilometer to 250 meters by correlating $\mathrm{ET}_{a}$ with the Normalized Difference Vegetation Index (NDVI) from the Moderate Resolution Imaging Spectroradiometer instrument (MODIS). Correlations were studied in three arid to semiarid irrigated landscapes of the Western United States (Escalante Valley near Enterprise, Utah; Palo Verde Valley near Blythe, California; and part of the Columbia Plateau near Quincy, Washington) during several periods from 2002 to 2008. Irrigation season $\mathrm{ET}_{a}$-NDVI correlations were lower than expected, ranging from $\mathrm{R}^{2}$ of 0.20 to 0.61 because of an eastward 2-3 kilometer shift in $\mathrm{ET}_{a}$ data. The shift is due to a similar shift identified in the land-surface temperature (LST) data from the MODIS Terra satellite, which is used in the SSEB model. Further study is needed to delineate the Terra LST shift, its effect on SSEB ET ${ }_{a}$, and the relation between $\mathrm{ET}_{a}$ and NDVI.
\end{abstract}

\section{Introduction}

Irrigation water use is an important and often poorly understood water-budget component. If actual evapotranspiration $\left(\mathrm{ET}_{a}\right)$ can be estimated sufficiently in irrigated areas, irrigation water use can be well defined. The Simplified Surface Energy Balance model (SSEB) has proven to be an effective tool for estimating $\mathrm{ET}_{a}$ (Senay and others, 2007; Senay and others, 2011a; Senay and others, 2011b).
However, resolution limitations ( $1 \mathrm{~km}$ ) of the Moderate Resolution Imaging Spectroradiometer (MODIS) land-surface temperature (LST) data constrain the use of the SSEB model to regional scale projects. The ability to downscale $\mathrm{SSEB} \mathrm{ET}_{a}$ would allow smaller scale studies, or those requiring a finer resolution, to use these valuable $\mathrm{ET}_{a}$ estimates.

$\mathrm{ET}_{a}$ shares a well-established, strong relation with the Normalized Difference Vegetation Index (NDVI; Senay and others, 2011a). NDVI is derived from information collected by MODIS aboard the National Aeronautics and Space Administration's (NASA's) Aqua and Terra satellites. NDVI is created from the red and near-infrared wavelengths, and is a measure of vegetation vigor. A 16-day NDVI composite, representing the maximum NDVI during the 16-day period, is available from each satellite every 16 days. The start date for each Aqua satellite composite is 8 days after the Terra satellite start date in order for a 16-day NDVI composite to be available from either satellite every 8 days. Data are available at several resolutions including $1 \mathrm{~km}$ and $250 \mathrm{~m}$. By defining the relation between $1 \mathrm{~km} \mathrm{ET}_{a}$ and $1 \mathrm{~km} \mathrm{NDVI}$, and applying it to the $250 \mathrm{~m} \mathrm{NDVI}, \mathrm{ET}_{a}$ could be downscaled to $250 \mathrm{~m}$, approaching field scale.

\section{Purpose and Scope}

This report presents the results of a study to investigate the correlation between $\mathrm{ET}_{a}$ and NDVI to assess downscaling feasibility. The correlation between NDVI and MODIS LST, a primary component of SSEB, also was studied. Correlations presented herein were investigated in three arid to semiarid irrigated landscapes of the Western United States (Escalante Valley near Enterprise, Utah; Palo Verde Valley near Blythe, California; and part of the Columbia Plateau near Quincy, Washington) during several periods from 2002 to 2008. 


\section{Evapotranspiration and Normalized Difference Vegetation Index for Downscaling Simplified Surface Energy Balance Model}

\section{Simplified Surface Energy Balance}

The SSEB model estimates $\mathrm{ET}_{a}$ using LST, air temperature, and reference ET data (Senay and others, 2011b). SSEB uses a simplified process adapted from the Surface Energy Balance Algorithm for Land (SEBAL; Bastiaanssen and others, 1998) and Mapping EvapoTranspiration at high Resolution and with Internalized Calibration (METRIC; Allen and others, 2007) models. When solving the energy balance at the land surface, SEBAL and METRIC both assume that the difference between LST and air temperature varies linearly with LST. SSEB further assumes that the difference between LST and air temperature also varies linearly with $\mathrm{ET}_{a}$. Cells with the greatest differences have little to no $\mathrm{ET}_{a}$. Cells with the smallest differences have the maximum $\mathrm{ET}_{a}$. This principle is executed in the SSEB model by calculating the ET fraction $\left(\mathrm{ET}_{f}\right) . \mathrm{ET}_{f}$ is calculated for every cell in the model by comparing its temperature difference to that of the minimum and maximum differences.

$\mathrm{ET}_{a}$ is computed as the product of the $\mathrm{ET}_{f}$ and the reference ET $\left(\mathrm{ET}_{o}\right)$. Parameter-elevation Regressions on Independent Slopes Model (PRISM) air temperature data (Daly and others, 1993) and MODIS Terra 1-km, 8-day LST data (MOD11A2; National Aeronautics and Space Administration Land Processes Distributed Active Archive Center, 2008) are used to calculate $\mathrm{ET}_{f}$. $\mathrm{ET}_{o}$ is generated from the Global Data Assimilation System (GDAS; Kanamitsu, 1989) using the standard Penman-Monteith equation for short-grass (Allen and others, 1998). $\mathrm{ET}_{o}$ values are based on the assumptions that cells are completely vegetated and that irrigation water is ample to meet crop demand. $\mathrm{ET}_{f}$ is calculated for every 8-day MODIS LST period, whereas ET is computed daily. Therefore, $\mathrm{ET}_{o}$ is responsible for daily variability in $\mathrm{ET}_{a}$. $\mathrm{All} \mathrm{ET}_{a}$ data analyzed in this report were first aggregated to a monthly time period.

\section{Methods}

Monthly 1-km ET ${ }_{a}$ data were created for Escalante Valley, Utah, in ESRI grid format and World Geodetic System 1984 (WGS84) datum using the methods described in Senay and others (2011b). Data were created for 2000-2009. The 1-km, 16-day MODIS NDVI data from Aqua (MYD13A2) and Terra (MOD13A2) satellites were downloaded from the NASA Land Processes Distributed Active Archive Center (National Aeronautics and Space Administration Land Processes Distributed Active Archive Center, 2008) for Escalante Valley, Utah, in hierarchical data format and Sinusoidal projection. These data were projected to WGS84 using the MODIS Reprojection Tool for Projection and Format Conversion (National Aeronautics and Space Administration Land Processes Distributed Active Archive Center, 2007).
Data were selected within the Escalante Valley and saved in ESRI grid format. ESRI ArcGIS 9.3.1 was used to process all GIS data for this report.

Maximum monthly NDVI (NDVImax) data were built from the 16-day data to compare NDVI to monthly $\mathrm{ET}_{a}$. An Escalante Valley focus area was delineated to include most irrigated lands and a buffer of native vegetation (fig. 1A). All $\mathrm{ET}_{a}$ and NDVImax data cells in this focus area were sampled in August 2002, 2005, and 2008. Additionally, data cells in this focus area were sampled in January and May 2008 to analyze correlations during winter and spring. Correlations between the sampled $\mathrm{ET}_{a}$ and NDVImax data were analyzed using Microsoft ${ }^{\circledR}$ Excel $^{\circledR}$ (table 1).

MODIS 1-km LST and NDVI data from the Aqua and Terra satellites were acquired for August 13, 2002; August 13, 2005; October 16, 2007; January 17, 2008; May 16, 2008; and August 4, 2008, and were not re-projected to avoid interpolation errors. These data were used to investigate differences between Aqua and Terra satellite data, and Terra LST's influence on SSEB ET ${ }_{a}$. LST is one of the primary data components of the SSEB model. LST-NDVI correlations were calculated and compared using the same methodology used to create the $\mathrm{ET}_{a}$-NDVImax correlations. LST and NDVI, however, are negatively correlated because of the cooling effect of evapotranspiration. LST and NDVI data were compared using individual tiles representing specific dates and times, rather than as monthly composites such as $\mathrm{ET}_{a}$ and NDVImax. LST is available every 8 days from both satellites occurring on the same dates. NDVI is available every 16 days from both satellites, alternating every 8 days. Because NDVI is available only from Aqua or Terra satellites for any given date, it was sometimes necessary to compare LST from one satellite with NDVI from the other satellite.

Findings from Escalante Valley were compared with those from two similar western irrigated landscapes: Palo Verde Valley near Blythe, California, and part of the Columbia Plateau near Quincy, Washington. The same methodologies described for the Escalante Valley were used, including establishing focus areas for cell sampling that include irrigated lands and a buffer of native vegetation. All three agricultural areas receive little precipitation during the growing season and typify irrigation regimes in arid and semiarid climatic regions of the Western United States. The Palo Verde Valley focus area contains all the irrigated land near Blythe, California, and is split between California and Arizona by the Colorado River. The Columbia Plateau focus area near Quincy, Washington, is contained between the Columbia River to the west, Sentinel Mountain to the south, Potholes Reservoir to the east, and Monument Hill to the north. For the Palo Verde Valley focus area, the August 4, 2008, LST-NDVI correlation was computed. For the Columbia Plateau focus area, the August 13, 2005, LST-NDVI and the August 2005 $\mathrm{ET}_{a}$-NDVImax correlations were computed. Columbia Plateau $\mathrm{ET}_{a}$ data are from a previous U.S. Geological Survey study (Kahle and others, 2011); data were not available for 2008. 


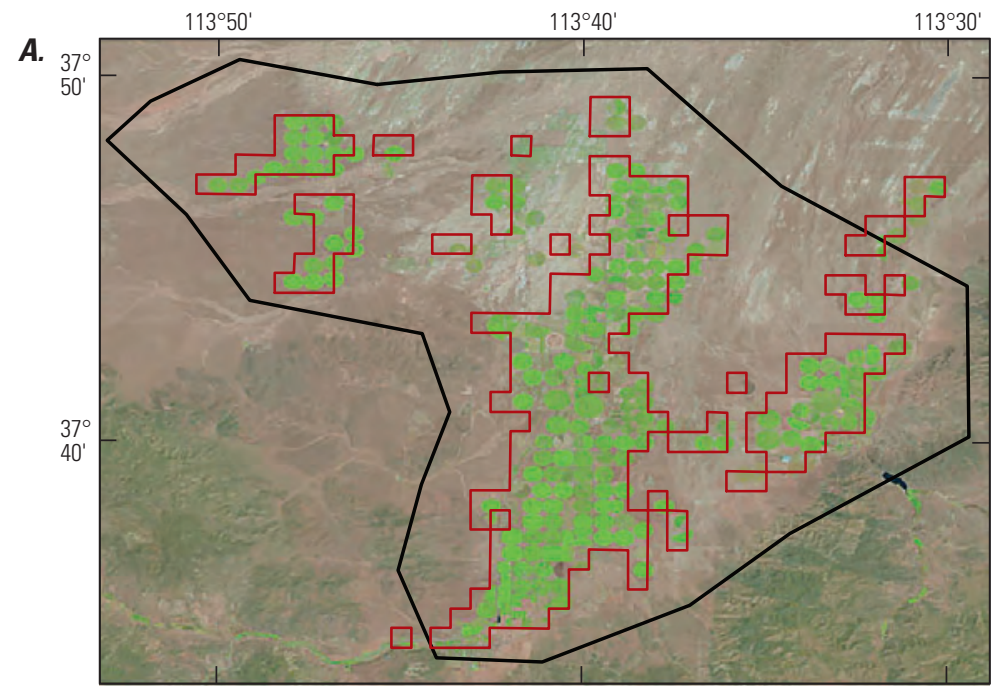

EXPLANATION

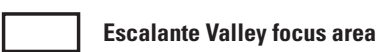

High value NDVI footprint

Landsat image August 14, 2008

(bands 1, 2, and 3). Irrigated areas

identified by bright green color.

B.

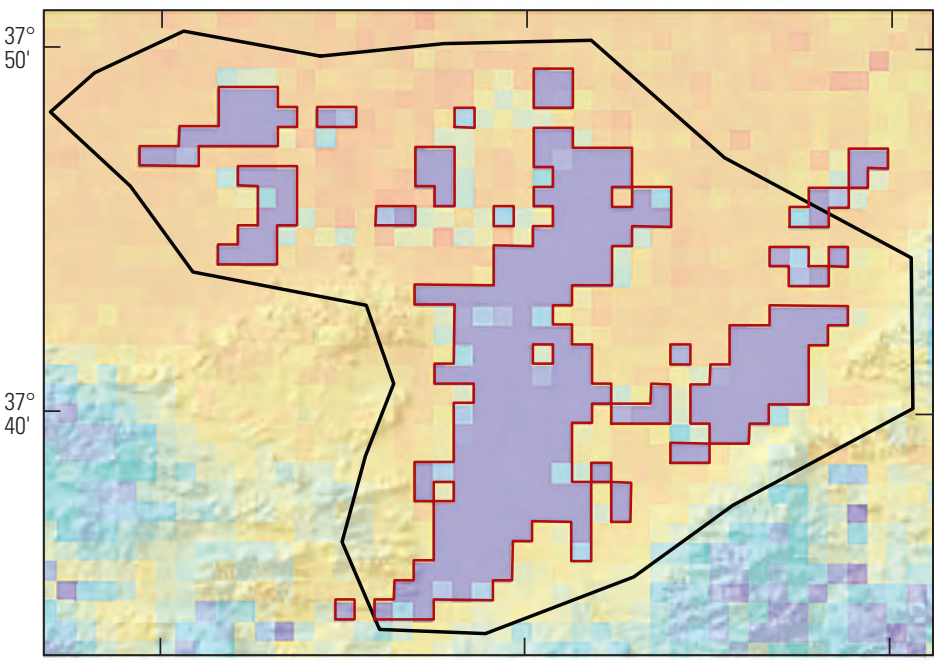

\section{Maximum NDVI, August 2008}

High : 0.9355
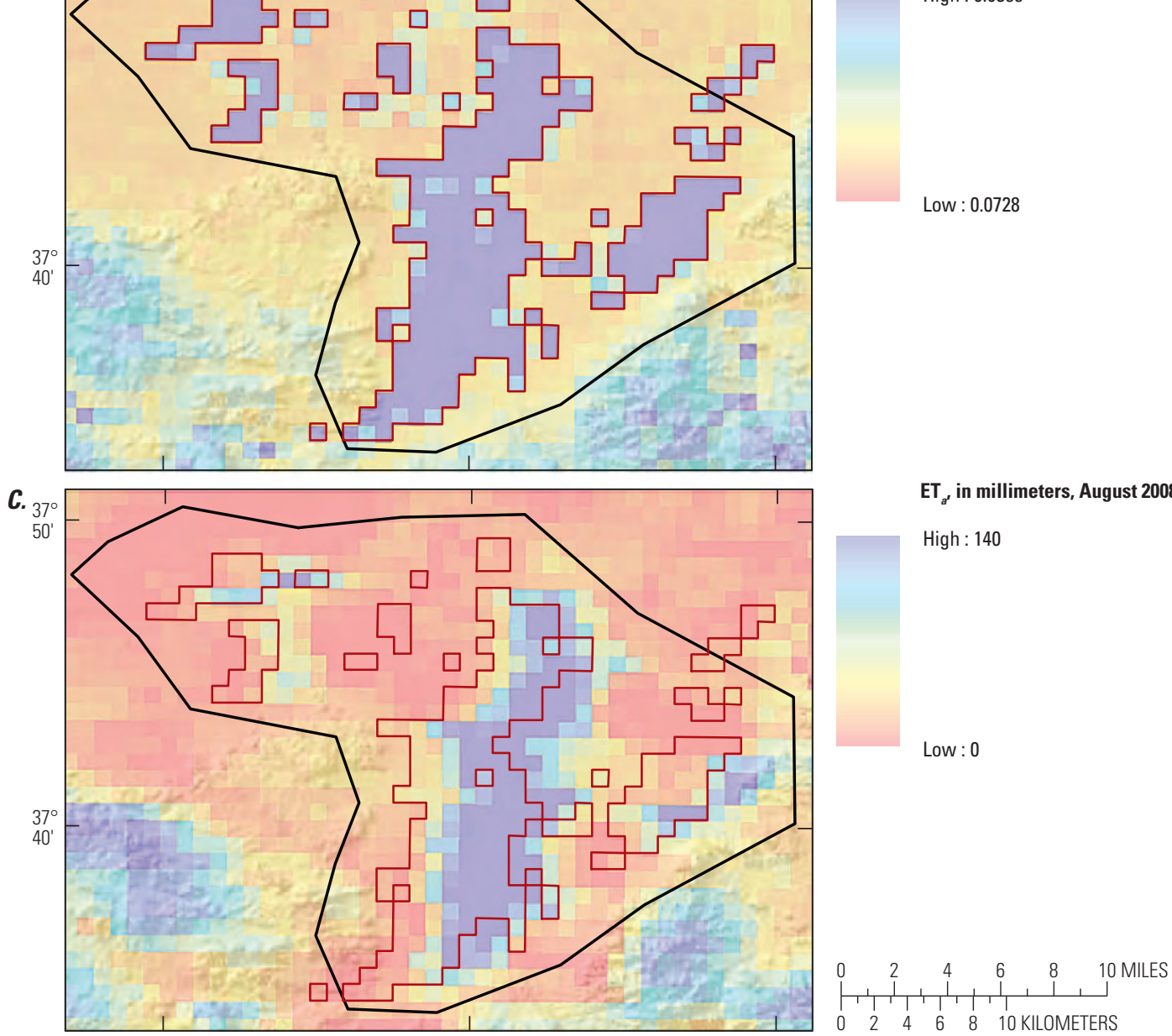

Basemap modified from USGS and other digital data, various scales.

Coordinate system: Geographic, World Geodetic System 1984

Figure 1. Eastward shift in actual evapotranspration $\left(\mathrm{ET}_{a}\right)$ compared to maximum monthly Normalized Difference Vegetation Index (NDVImax) and Landsat, Escalante Valley focus area near Enterprise, Utah. (A) Landsat image August 14, 2008 (bands 1, 2, and 3); (B) NDVImax, August 2008; (C) Simplified Surface Energy Balance (SSEB ET ${ }_{a}$ ), August 2008. 
Table 1. Correlations between Simplified Surface Energy Balance derived actual evapotranspiration, Moderate Resolution Imaging Spectroradiometer (MODIS) Normalized Difference Vegetation Index, maximum monthly Normalized Difference Vegetation Index, and MODIS land-surface temperature for the Escalante Valley, Utah, Palo Verde Valley, California, and Columbia Plateau, Washington, focus areas.

[ $\mathbf{R}^{2}$ of NDVI, and Aqua satellite and Terra satellite LST: Correlations between various Normalized Difference Vegetation Index (NDVI) and landsurface temperature (LST) data. $\mathbf{R}^{2}$ of NDV Imax and E T : Correlation of maximum monthly NDVI and actual evapotranspiration. - , not applicable]

\begin{tabular}{|c|c|c|c|c|}
\hline Focus area & Date & $\begin{array}{c}\mathbf{R}^{2} \text { of } \\
\text { NDVI,and } \\
\text { Aqua } \\
\text { satellite LST }\end{array}$ & $\begin{array}{l}\mathrm{R}^{2} \text { of NDVI, } \\
\text { and Terra } \\
\text { satellite LST }\end{array}$ & $\begin{array}{c}\mathrm{R}^{2} \text { of } \\
\text { NDVImax, } \\
\text { and } \mathrm{ET}_{a}\end{array}$ \\
\hline \multirow[t]{11}{*}{ Escalante Valley } & $08-13-2002$ & ${ }^{1} 0.61$ & ${ }^{10} 0.33$ & - \\
\hline & 08-13-2005 & ${ }^{1} 0.60$ & ${ }^{1} 0.40$ & - \\
\hline & $10-16-2007$ & ${ }^{1} 0.48$ & ${ }^{1} 0.29$ & - \\
\hline & 01-17-2008 & ${ }^{1} 0.02$ & ${ }^{10} 0.01$ & - \\
\hline & 05-16-2008 & ${ }^{2} 0.69$ & 20.43 & - \\
\hline & 08-04-2008 & ${ }^{2} 0.46$ & ${ }^{2} 0.24$ & - \\
\hline & ${ }^{3} 08-2002$ & - & - & 0.30 \\
\hline & ${ }^{3} 08-2005$ & - & - & 0.45 \\
\hline & ${ }^{3} 01-2008$ & - & - & 0.02 \\
\hline & ${ }^{3} 05-2008$ & - & - & 0.21 \\
\hline & ${ }^{3} 08-2008$ & - & - & 0.20 \\
\hline Palo Verde Valley & 08-04-2008 & ${ }^{2} 0.72$ & ${ }^{2} 0.50$ & - \\
\hline \multirow[t]{2}{*}{ Columbia Plateau } & 08-13-2005 & ${ }^{1} 0.59$ & ${ }^{1} 0.50$ & - \\
\hline & ${ }^{3} 08-2005$ & - & - & 0.61 \\
\hline
\end{tabular}

${ }^{1}$ MODIS NDVI from the Terra satellite.

${ }^{2}$ MODIS NDVI from the Aqua satellite.

${ }^{3}$ Represents a monthly aggregate.

\section{Results}

The August 2002, 2005, and $2008 \mathrm{ET}_{a}$ and NDVImax data were sampled and correlations were determined for the Escalante Valley focus area. In all cases, the correlations between $\mathrm{ET}_{a}$ and NDVImax were poor, with $\mathrm{R}^{2}$ values ranging from 0.20 to 0.45 (table 1). Analyses of January and May 2008 data also indicated poor correlations, with $\mathrm{R}^{2}$ values equal to 0.02 and 0.21 , respectively.

Visual inspection of the August 2002, 2005, and 2008 data and the January and May 2008 data showed an eastward 2-3 km shift in $\mathrm{ET}_{a}$ cells when compared to NDVImax (fig. $\underline{1 C}$ ). The poor $\mathrm{ET}_{a}$-NDVImax correlations that were observed are likely caused by this shift. The shift is most easily seen when comparing high-value $\mathrm{ET}_{a}$ cells with high-value NDVImax cells. The high-value NDVImax cell footprint in figure $1 B$ is used in figures $1 A$ and $\underline{\underline{1 C}}$ as a frame of reference. The locations of center pivot circular irrigated fields using Landsat imagery (identified in bright green; fig. 1A) matched well with NDVImax indicating that the NDVI data are accurate and that the shift is a result of one or more of the data sets used to calculate $\mathrm{ET}_{a}$.
MODIS LST data, a component of SSEB ET ${ }_{a}$, were investigated to determine if those data were responsible for the observed shift. The LST data from both the Aqua and Terra satellites were compared to the NDVI. A similar but smaller shift (1-2 km) was inherent in all LST data from the Terra satellite (fig. 2C). MODIS LST data from the Aqua satellite, however, only show possible traces of shifting compared to NDVI (fig. 2B). MODIS NDVI from Aqua and Terra satellites show no indications of shifting when compared to each other or to the Landsat imagery. This visual analysis is corroborated by the Aqua-Terra LST correlation and the Aqua-Terra NDVI correlation in August 2008 (fig. 3). Aqua LST and Terra LST from August 4, 2008, show a moderate correlation $\left(R^{2}=0.64\right)$ because of the Terra LST shift. Aqua NDVI and Terra NDVI from August 4 and August 12, 2008, respectively, show a strong correlation $\left(\mathrm{R}^{2}=0.96\right)$ because of no shift.

LST and NDVI data from Aqua and Terra satellites were sampled and correlations were determined for August 13, 2002; August 13, 2005; October 16, 2007; January 17, 2008; May 16, 2008; and August 4, 2008. Similar to the $\mathrm{ET}_{a}$-NDVImax relation, correlations between Terra LST and NDVI were poor because of the Terra LST shift. $\mathrm{R}^{2}$ values ranged from 0.24 to 0.40 for August 13, 2002; August 13, 2005; and August 4, 2008 (table 1). The Aqua LST-NDVI correlation consistently was better than the Terra LST-NVDI correlation because of no shift, with $\mathrm{R}^{2}$ values ranging from 0.46 to 0.61 .

MODIS LST and NDVI both use a Sinusoidal grid tiling system, with each tile equal to $10 \times 10$ degrees starting at the equator (National Aeronautics and Space Administration Land Processes Distributed Active Archive Center, 2012). The Escalante Valley is on the margins between two MODIS tiles (h08v05 and h09v05). One possibility is that shifting is occurring on the margins of the tiles because of distortion. To rule out the position on the tile as the cause of shifting, correlations were analyzed for the Palo Verde Valley and Columbia Plateau focus areas.

The Palo Verde Valley is located near the center of the western MODIS tile (h08v05) shared by the Escalante Valley. Visual inspection of the imagery showed a similar shift of Terra LST compared to Aqua and Terra NDVI, and Aqua LST. LST and NDVI data were sampled in the irrigated and adjacent area for August 4, 2008. Aqua and Terra correlations showed improvement compared to correlations in Escalante Valley; however, the difference in correlations between Aqua and Terra satellites was consistent with those of Escalante Valley because of shifting (Aqua $\mathrm{R}^{2}=0.72$; Terra $\mathrm{R}^{2}=0.50$ ).

The Columbia Plateau focus area lies in the northeastern quarter of the adjacent MODIS tile (h09v04). $\mathrm{ET}_{a}$ and NDVImax data were sampled for August 2005, with $\mathrm{R}^{2}=0.61$. LST and NDVI data were sampled for August 13, 2005, with $\mathrm{R}^{2}=0.50$ for Terra satellite and $\mathrm{R}^{2}=0.59$ for Aqua satellite. In this case, the $\mathrm{ET}_{a}$-NDVImax correlation is similar to the Aqua LST-NDVI correlation. The difference between Aqua and Terra LST-NDVI correlations is much smaller than in the previous examples. Visually, the Aqua-Terra LST shift is still persistent; however, the $\mathrm{ET}_{a}$-NDVI shift is more subtle. 

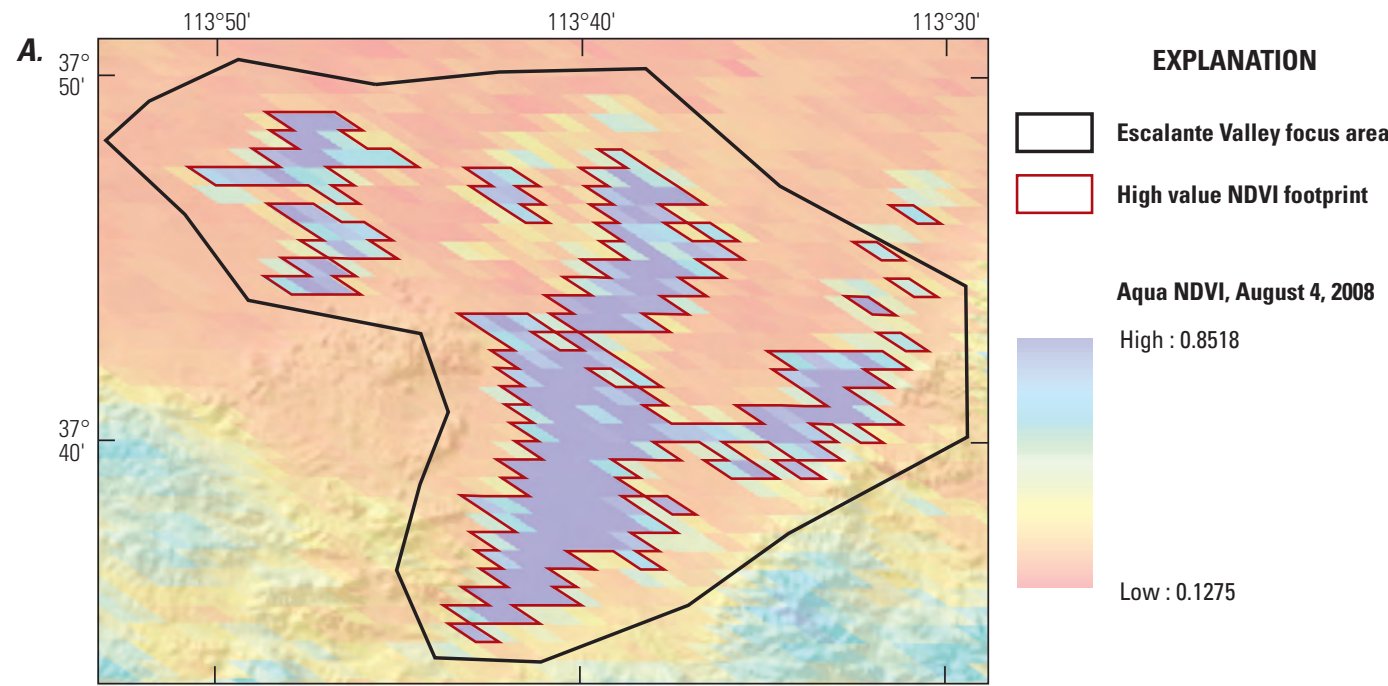

\section{Aqua NDVI, August 4, 2008}

High : 0.8518

B. 37

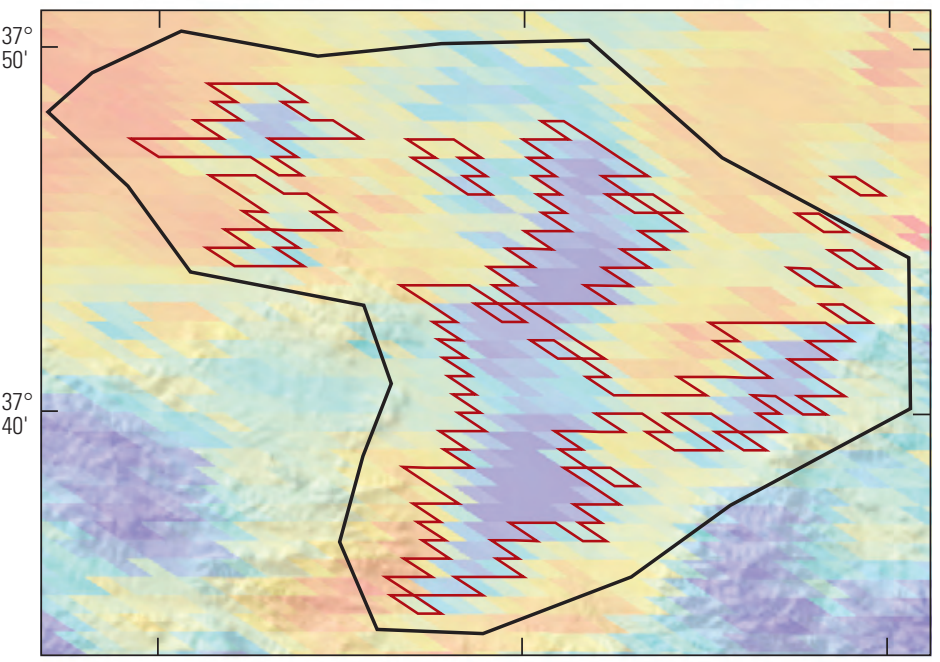

\section{Aqua LST, in degrees Celsius, August 4, 2008}

High : 51.31

C. 3
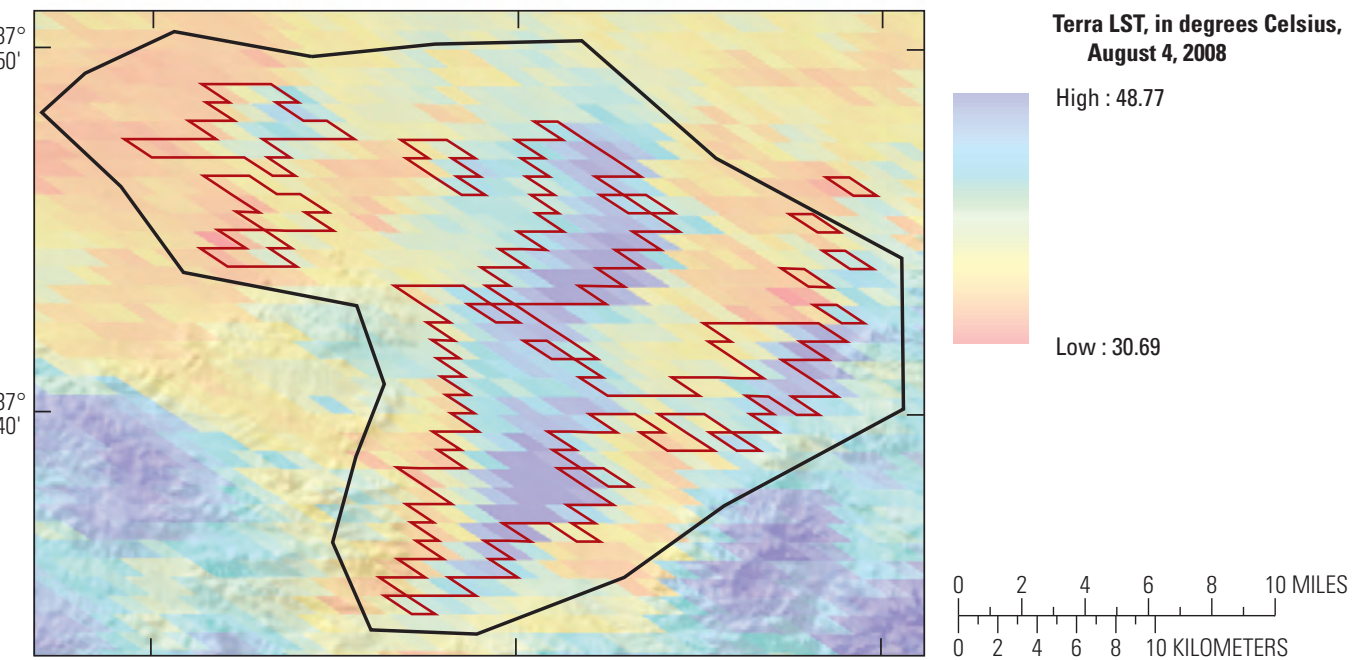

Basemap modified from USGS and other digital data, various scales.

Coordinate system: Geographic, World Geodetic System 1984

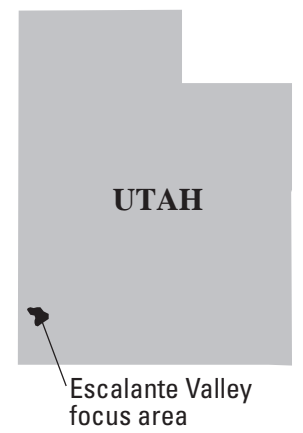

Figure 2. Eastward shift in Moderate Resolution Imaging Spectroradiometer (MODIS) Terra land-surface temperature (LST) compared to MODIS Aqua LST and Normalized Difference Vegetation Index (NDVI), Escalante Valley focus area near Enterprise, Utah. (A) MODIS Aqua NDVI, August 4, 2008; (B) MODIS Aqua LST, August 4, 2008; (C) MODIS Terra LST, August 4, 2008. 


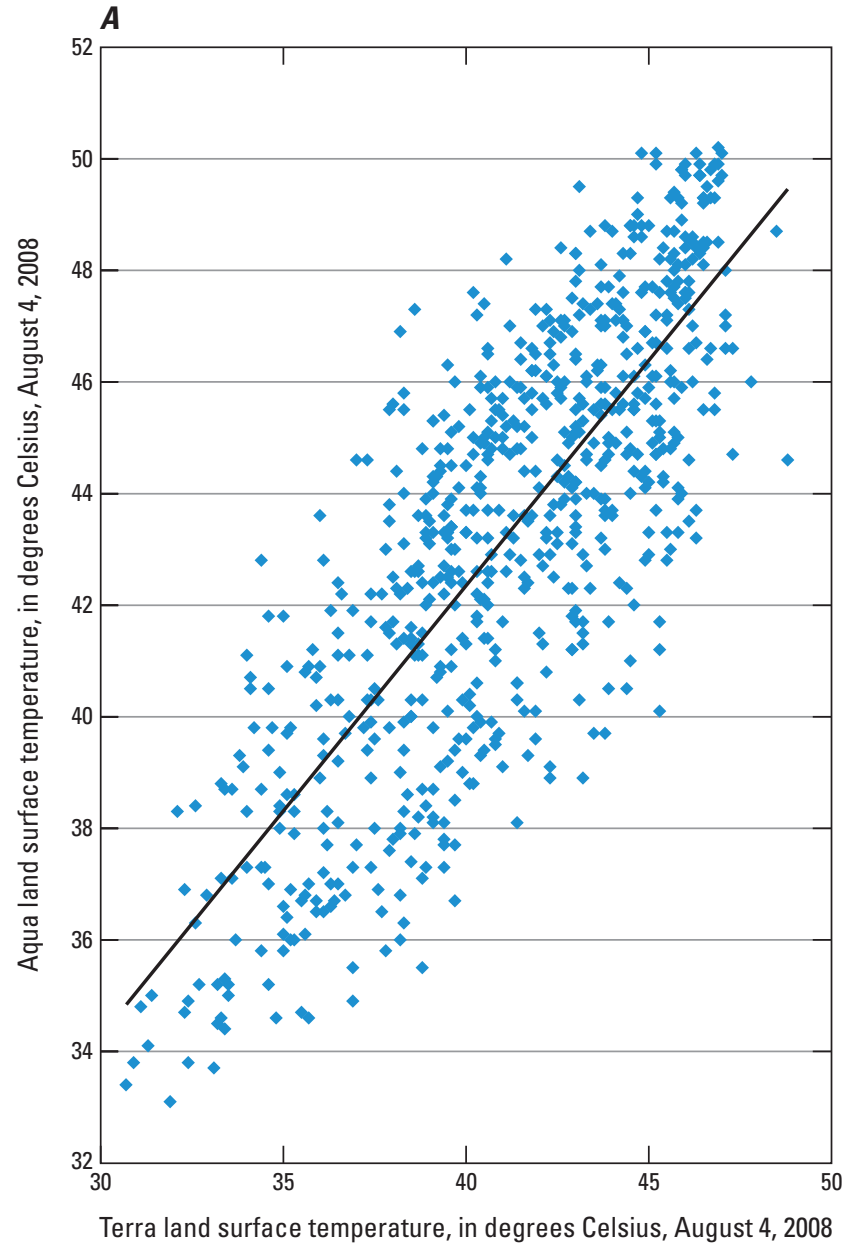

EXPLANATION

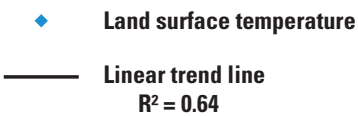

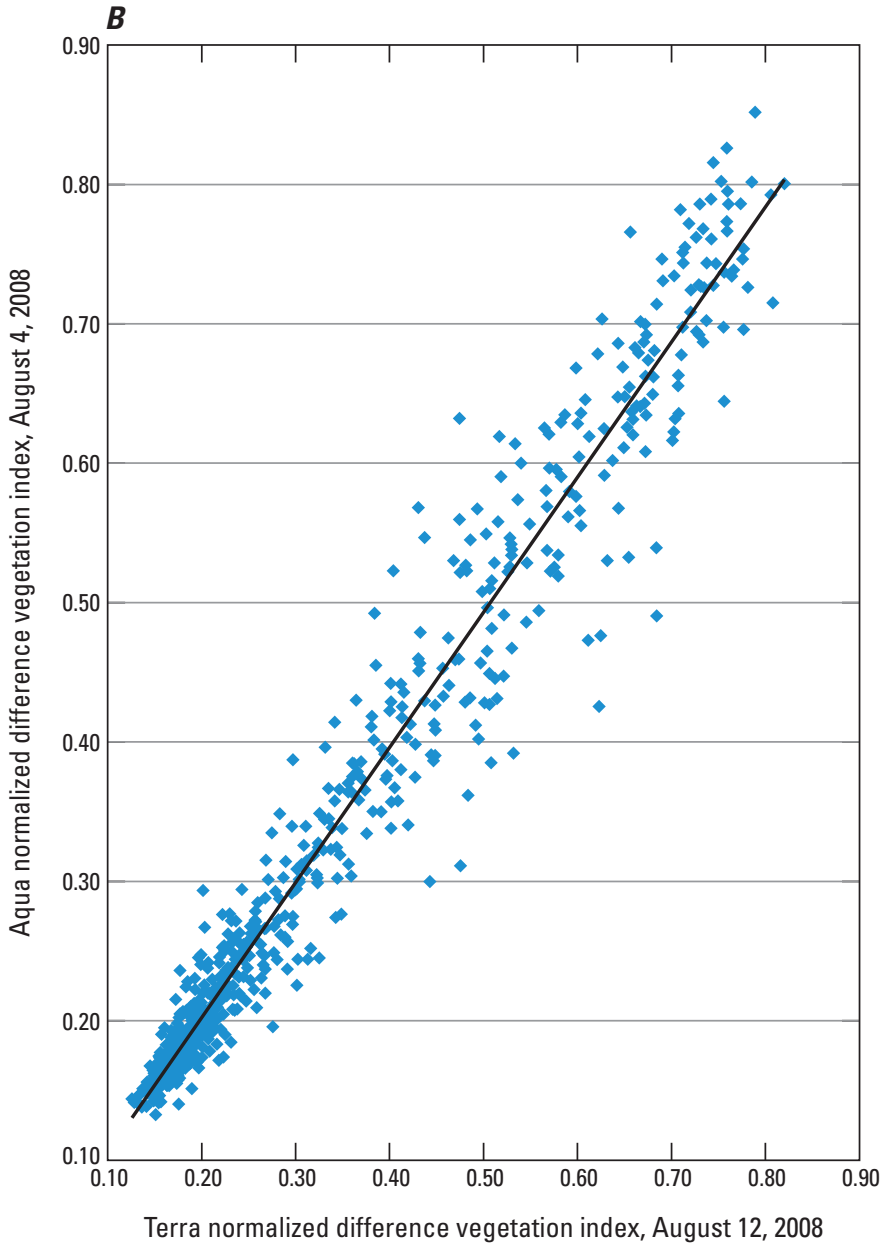

EXPLANATION

- Normalized difference vegetation index

Linear trend line $\mathrm{R}^{2}=0.96$

Figure 3. Aqua and Terra satellite correlations for land-surface temperature (LST) and Normalized Difference Vegetation Index (NDVI), Escalante Valley focus area near Enterprise, Utah. (A) Aqua and Terra LST, August 4, 2008; (B) Aqua and Terra NDVI, August 4 and August 12, 2008, respectively. 


\section{Summary}

A strong correlation between actual evaporotranspiration $\left(\mathrm{ET}_{a}\right)$ and Normalized Difference Vegetation Index (NDVI) is required to downscale 1-kilometer-resolution Simplified Surface Energy Balance (SSEB) $\mathrm{ET}_{a}$ data to 250-meterresolution data. $\mathrm{ET}_{a}$-maximum monthly NVDI (NDVImax) correlations calculated for this study do not meet this criterion. A 1-2-kilometer eastern shift in Terra Moderate Resolution Imaging Spectroradiometer land-surface temperature (MODIS LST) data negatively influences this relation and translates to a 2-3-kilometer shift in SSEB ET ${ }_{a}$. However, it is uncertain how much the $\mathrm{ET}_{a}$-NDVImax correlation could improve if only Aqua LST data are used in the SSEB model (in the Columbia Plateau, the Aqua LST-NDVI correlation is only slightly greater than the Terra LST-NDVI correlation). Correlations between $\mathrm{ET}_{a}$ and NDVImax possibly could improve, but not enough to be sufficient for downscaling. Further study is needed to delineate the Terra LST shift, its effect on SSEB $\mathrm{ET}_{a}$, and the relation between $\mathrm{ET}_{a}$ and NDVI.

\section{References Cited}

Allen, R.G., Pereira, L.S., Raes, Dirk, and Smith, Martin, 1998, Crop evapotranspiration - Guidelines for computing crop water requirements-FAO irrigation and drainage paper 56: Rome, Italy, Food and Agricultural Organization of the United Nations.

Allen, R.G., Tasumi, M., and Trezza, R., 2007, Satellitebased energy balance for mapping evapotranspiration with internalized calibration (METRIC) - Applications: American Society of Civil Engineers Journal of Irrigation and Drainage Engineering, v. 133, no. 4, p. 395-406.

Bastiaanssen, W.G.M., Menenti, M., Feddes, R.A., and Holtslag, A.A.M., 1998, A remote sensing surface energy balance algorithm for land (SEBAL) - 1 . Formulation: Journal of Hydrology, v. 212-213, p. 198-212.

Daly, C., Neilson, R.P., and Phillips, D.L., 1993, A statisticaltopographic model for mapping climatological precipitation over mountainous terrain: Journal of Applied Meteorology, v. 33 , no. 2 , p. $140-158$.
Kahle, S.C., Morgan, D.S., Welch, W.B., Ely, D.M., Hinkle, S.R., Vaccaro, J.J., and Orzol, L.L., 2011, Hydrogeologic framework and hydrologic budget components of the Columbia Plateau Regional Aquifer System, Washington, Oregon, and Idaho: U.S. Geological Survey Scientific Investigations Report 2011-5124, 66 p. (Also available at http://pubs.er.usgs.gov/publication/sir20115124.)

Kanamitsu, M., 1989, Description of the NMC Global Data Assimilation and Forecast System: American Meteorological Society Weather and Forecasting, v. 4, no. 3, p. 335-342.

National Aeronautics and Space Administration Land Processes Distributed Active Archive Center, 2007, MODIS Reprojection Tool version 4.0: U.S. Geological Survey-Earth Resources Observation and Science (EROS) Center, Sioux Falls, South Dakota.

National Aeronautics and Space Administration Land Processes Distributed Active Archive Center, 2008, MOD11A2, MYD11A2, MOD13A2, and MYD13A2: U.S. Geological Survey-Earth Resources Observation and Science (EROS) Center, Sioux Falls, South Dakota.

National Aeronautics and Space Administration Land Processes Distributed Active Archive Center, 2012, MODIS Overview; U.S. Geological Survey web site, accessed August 14, 2012, at https://lpdaac.usgs.gov/products/ modis overview.

Senay, G.B., Budde, M., and Verdin, J.P., 2011a, Enhancing the simplified surface energy balance approach for estimating landscape ET - Validation with the METRIC model: Agricultural Water Management, v. 98 , no. 4, p. 606-618.

Senay, G.B., Budde, M., Verdin, J.P., and Melesse, A.M., 2007, A coupled remote sensing and simplified surface energy balance approach to estimate actual evapotranspiration from irrigated fields: Sensors, v. 7, no. 6, p. $979-1,000$.

Senay, G.B., Leake, S., Nagler, P.L., Artan, G.A., Dickinson, J., Cordova, J.T., and Glenn, E.P., 2011b, Estimating basin scale evapotranspiration (ET) by water balance and remote sensing methods: Hydrological Processes, v. 25, no. 26, p. $4,037-4,049$. 
8 Evapotranspiration and Normalized Difference Vegetation Index for Downscaling Simplified Surface Energy Balance Model

This page intentionally left blank 
For more information concerning the research in this report, contact the Director, Washington Water Science Center

U.S. Geological Survey, 934 Broadway, Suite 300

Tacoma, Washington 98402

http://wa.water.usgs.gov 


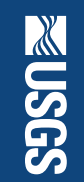

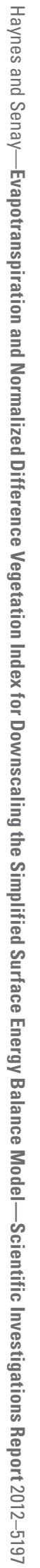

